\title{
INCOME DISTRIBUTION INEQUALITY IN WEST SUMATERA AND THE RELATED FACTORS
}

\author{
Putri Irina Mayang Sari ${ }^{1}$, Sri Mulatsih ${ }^{2}$ dan Idqan Fahmi ${ }^{3}$ \\ Department of Economics, Faculty of Economics and Management, Bogor Agricultural University, \\ Darmaga Campus, Bogor 16680, Indonesia
}

Artikel diterima Februari 2013

Artikel disetujui untuk dipublikasikan Juli 2014

\begin{abstract}
Causal relationship between inequality and growth is far from being well understood. In West Sumatera the higher level of growth rate followed by an increasing in Gini ratio or increasing in income inequality. A sharp rise of income inequality has caused discussion about factors affecting inequality. Objectives of this research are to analyze income inequality condition in each Regency/Municipality in West Sumatera and to analyze the factors affecting income inequality. Through the calculation of the Gini ratio, it was found that the highest income distribution inequality in Regency/Municipality level in West Sumatra from 2006 to 2011 are owned by the Mentawai Islands District with an average Gini ratio is 0.311, while the lowest income distribution inequality of the average owned by the Pesisir Selatan District with an average Gini ratio is 0.217. This research is investigated by analyzing a balance panel data with 19 districts from 2006 to 2011. This study found that there are seven variables which can be associated with a movement in income inequality. Income per capita, routine spending for government officials and dummy earthquake have a positive relationship with income distribution inequality. Meanwhile, industrial sector's share toward Gross Regional Domestic Products (GRDP), government spending for development program, number of workers in industry and population growth have negative impact.
\end{abstract}

Key words: income distribution, inequality, earthquake, west sumatera

\section{INTRODUCTION}

The relation between income distribution inequality and economic performance has always been debated not only by economist but also by policy makers (Eicher dan García-Peñalosa 2000). On one hand, growth rate of per capita income is a very important indicator to prosperity benchmark and rate of development of a country. While on the other side, growth rate of per capita income is often linked with the increase of income distribution inequality. The influence of per capita income towards income distribution inequality is known as inverted U-shape relation which is also known as Kuznets curve. The first research regarding this curve was conducted by Kuznets in 1995 and in the first stage claimed that per capita income growth tend to raise income distribution inequality (Barro 2008).

*Corresponding autor. Phone: +6285761587312
Email: putri.irina.mayang@gmail.com

The relation between growth and income distribution inequality is observed in West Sumatera. Relatively high economic growth is followed by the raise of income distribution inequality. According to Kajian Ekonomi Regional Sumatera Barat, West Sumatera's growth on the first quarter of 2013 is $7.2 \%$, higher than national economic growth in the same year which is 6.0\% (Bank Indonesia 2013). The high economic growth is followed by income distribution inequality as shown by Gini ratio.

Income distribution inequality causes many problems. Todaro and Smith (2006) argues that income inequality will cause economic inefficiency, asset allocation is not efficient and weaken social \& solidarity stability. Arsyad (1997) claims income distribution inequality will trigger poverty. Basdevant et al. (2012) on the other notes states that income distribution inequality will influence country's economic 
growth duration. Based on the background and problem statements mentioned above, the objectives of this research are:

1.Analyzing income distribution inequality in each Regency/Municipality in West Sumatera.

2.Analyzing the factors affecting income distribution inequality in West Sumatera.

\section{RESEARCH METHODS}

Data used in this research are secondary data obtained from BPS-Statistic Indonesia. The data are time series data from 2006-2011 and cross section Regency/Municipality in West Sumatera. Moreover, SUSENAS data are also used to calculate Gini ratio for 19 Regency/Municipality in West Sumatera. The type of data in this research is shown below.

Table 1 . Type of data

\begin{tabular}{|l|l|l|}
\hline Data & Criteria & Indicator \\
\hline $\begin{array}{l}\text { Growth and } \\
\text { development rate }\end{array}$ & $\begin{array}{l}\text { 1. Growth } \\
\text { 2. Economic structure }\end{array}$ & $\begin{array}{l}\text { - GRDP per capita } \\
\text { - Industrial sector's share } \\
\text { towards GRDP } \\
\text { - Number of workers in } \\
\text { industrial sector }\end{array}$ \\
\hline $\begin{array}{l}\text { Macroeconomic } \\
\text { factors }\end{array}$ & Govemment spending & $\begin{array}{l}\text { - Routine spending for } \\
\text { govemment officials } \\
\text { - Development program }\end{array}$ \\
\hline Demographic factor & Population & - Population growth \\
\hline Natural disaster & Earthquake & - Dummy earthquake \\
\hline
\end{tabular}

To achieve the first objective of this research, which is analyzing income distribution inequality Regency/ Municipality in West Sumatera, Gini ratio calculation in 19 Regency/ Municipality in West Sumatera is performed from 2006 to 2010 using SUSENAS data, while for the year 2011, Gini ratio is obtained from Badan Pusat Statistik. Mathematically, Ray (1998) presents a formula to calculate Gini ratio:

$$
G=1-\sum_{i=1}^{m} f_{p i} \times\left(F_{c i}-F_{c i-1}\right)
$$

where:

$\mathrm{G}$ : Gini ratio, $f_{p i}$ : population frequency on $i$-th spending group, $F_{c i}$ : cumulative frequency of total spending on $i$-th spending group, $F_{c i-1}$ : cumulative frequency of total spending on $i-1$-th spending group.

The second objective of this research is achieved using data panel analysis for 19 Regency/Municipality in West Sumatera from year of 2006 to 2011. Model data panel specification that is used refers to modified Kassa (2003) research model. Modification involves adding natural disaster (dummy earthquake) as one of the indicators and removing share of urban population, share of young population (under 15), population density, inflation, unemployment, share of private sector toward GDP, share of service sector towards GDP, school participation rate and government spending for human capital. Reduction is carried out after conducting simulation to choose the best model. Based on simulation, model specification of income distribution inequality in West Sumatera is as follow:

$$
\begin{aligned}
& G I N I_{i t}=\delta_{0}+\delta_{1} \ln \_K A P_{i t}+\delta_{2} \ln \_S I N D_{i t}+ \\
& \delta_{3} \ln \_L I N D_{i t}+\delta_{4} \ln \_B L J P G W_{i t}+ \\
& \delta_{5} \ln _{-} N B L J_{i t}+\delta_{6} G P O P_{i t}+\delta_{7} D U M_{i t}+ \\
& \varepsilon_{i t} \\
& \text { GINI }=\text { Gini ratio } \\
& \text { KAP }=\text { GRDP per capita (million rupiah) } \\
& \text { SIND = Industrial sector's share towards GRDP } \\
& \text { LIND = Number of workers in industry (people) } \\
& \text { BLJPGW= Routine spending for government } \\
& \text { officials (million rupiah) } \\
& \text { NBLJ = Government spending for development } \\
& \text { program (million rupiah) } \\
& \text { GPOP = Population growth (percent) } \\
& \text { DUM = Dummy variable, value } 1 \text { for } \\
& \text { Regency/Municipality after strucked by } \\
& \text { earthquake, value } 0 \text { for others. } \\
& \ln \quad=\text { natural logarithm } \\
& \varepsilon \quad=\text { error term } \\
& \delta_{0} \quad=\text { constant/intercept } \\
& \mathrm{i} \quad=\text { Regency/Municipality in West Sumatera } \\
& =\text { year }
\end{aligned}
$$

Decision to choose the model used in data panel analysis is based on Hausman test. Hausman test is done to choose whether the model used is Fixed Effect or Random Effect (Firdaus 2011). Fixed Effect is used if the Hausman test showed rejection of the null hypothesis. in other hand Random Effect used if the Hausman test did not reject null hypothesis. Classical assumption check is not needed if the best model obtained is Random Effect, because the method in random effect is Generalized Least Square (GLS) which automatically lower the concern for auto correlation and 
heteroscedasticity so the residuals of the model must be normally distributed (Gujarati, 2004).

\section{INCOME DISTRIBUTION INEQUALITY IN WEST SUMATERA}

Kab. Mentawai Island has the highest average Gini ratio as compared to other Regency/Municipality in West Sumatera. This indicates that Kab. Mentawai Island has the worst income distribution inequality from 2006 to 2011. On the other hand, Kabupaten Pesisir Selatan has the lowest average income distribution inequality. High variation of Gini ratio in each Regency/Municipality in West Sumatera is due to several factors that will be discussed in the next section.

Income distribution inequality in West Sumatera shows various trends and there is a tendency to increase. In 2011, Kota Padang is the area that has highest inequality with Gini ratio of 0.399 , while the lowest inequality went to 50 Kota Regency with Gini ratio of 0.255 . These figures are very different if compared with 2006 data where highest Gini ratio was at 0.312 by Kota Solok and the lowest one went to Pesisir Selatan Regency with Gini ratio of 0.212. Table below shows Gini ratio in each Regency/Municipality in West Sumatera:

Table 2. Gini ratio index in each regency/municipallity In West Sumatera

\begin{tabular}{|l|c|c|c|c|c|c|c|}
\hline Regency/Municipality & $\mathbf{2 0 0 6}$ & $\mathbf{2 0 0 7}$ & $\mathbf{2 0 0 8}$ & $\mathbf{2 0 0 9}$ & $\mathbf{2 0 1 0}$ & $\mathbf{2 0 1 1}$ & Average \\
\hline Kep. Mentawai & 0.304 & 0.325 & 0.327 & 0.276 & 0.309 & 0.326 & 0.311 \\
\hline Kab. Pesisir Selatan & 0.212 & 0.194 & 0.217 & 0.195 & 0.219 & 0.264 & $\mathbf{0 . 2 1 7}$ \\
\hline Kab. Solok & 0.285 & 0.285 & 0.283 & 0.278 & 0.237 & 0.285 & 0.276 \\
\hline Kab. Sijunjung & 0.268 & 0.222 & 0.308 & 0.284 & 0.279 & 0.299 & 0.276 \\
\hline Kab. TanahDatar & 0.261 & 0.249 & 0.234 & 0.272 & 0.247 & 0.345 & $\mathbf{0 . 2 6 8}$ \\
\hline Kab. Padang Pariaman & 0.265 & 0.210 & 0.268 & 0.297 & 0.244 & 0.314 & 0.266 \\
\hline Kab. Agam & 0.274 & 0.264 & 0.257 & 0.258 & 0.256 & 0.277 & 0.264 \\
\hline Kab. 50 Kota & 0.221 & 0.203 & 0.258 & 0.242 & 0.228 & 0.255 & $\mathbf{0 . 2 3 4}$ \\
\hline Kab. Pasaman & 0.268 & 0.220 & 0.271 & 0.261 & 0.255 & 0.291 & $\mathbf{0 . 2 6 1}$ \\
\hline Kab. Solok Selatan & 0.242 & 0.204 & 0.262 & 0.287 & 0.270 & 0.292 & 0.259 \\
\hline Kab. Dhamasraya & 0.268 & 0.258 & 0.258 & 0.264 & 0.298 & 0.369 & $\mathbf{0 . 2 8 6}$ \\
\hline Kab. Pasaman Barat & 0.220 & 0.254 & 0.228 & 0.247 & 0.233 & 0.268 & $\mathbf{0 . 2 4 2}$ \\
\hline Kota Padang & 0.285 & 0.217 & 0.278 & 0.284 & 0.289 & 0.304 & $\mathbf{0 . 2 7 6}$ \\
\hline Kota Solok & 0.312 & 0.256 & 0.295 & 0.266 & 0.234 & 0.345 & $\mathbf{0 . 2 8 5}$ \\
\hline Kota SawahLunto & 0.280 & 0.263 & 0.288 & 0.251 & 0.282 & 0.336 & $\mathbf{0 . 2 8 3}$ \\
\hline Kota Padang Panjang & 0.309 & 0.255 & 0.231 & 0.273 & 0.309 & 0.399 & $\mathbf{0 . 2 9 6}$ \\
\hline Kota Bukittingg & 0.290 & 0.239 & 0.311 & 0.311 & 0.287 & 0.329 & $\mathbf{0 . 2 9 4}$ \\
\hline Kota Payakumbuh & 0.291 & 0.304 & 0.271 & 0.269 & 0.263 & 0.320 & $\mathbf{0 . 2 8 6}$ \\
\hline Kota Pariaman & 0.259 & 0.220 & 0.279 & 0.293 & 0.282 & 0.349 & $\mathbf{0 . 2 8 0}$ \\
\hline
\end{tabular}

\section{FACTORS AFFECTING INCOME DISTRIBUTION INEQUALITY IN WEST SUMATERA}

From Hausman test, probability value of 0.1127 is obtained (Table 3 ), this suggests not to reject null hypothesis and can be concluded that income distribution inequality model estimation is using Random Effect Method (REM). The use of REM reflects that there is no correlation between individual effect and free variable in the model.

Table 3. Hausman test result

\begin{tabular}{|l|c|c|c|}
\hline Test Summary & Chi-Sq. Statistic & Chi-Sq. d.f. & Prob. \\
\hline Cross-section random & 11.648180 & 7 & 0.1127 \\
\hline
\end{tabular}

Parameter testing of estimation result as a whole using F-test gives $\mathrm{F}$ statistic value of 9.919753 and probability of 0.000000 , so the results are significant at the $1 \%$ significance level.

Table 4. Estimation result of income distribution inequality model

\begin{tabular}{|l|ll|}
\hline \multicolumn{1}{c}{ Variable } & \multicolumn{1}{c|}{ Coefficient } & Prob. \\
\hline GPOP & $-0.030093^{* * *}$ & 0.0543 \\
\hline BLJPGW & $0.017330^{* * * *}$ & 0.0617 \\
\hline SIND $^{+}$ & $-0.031069^{*}$ & 0.0003 \\
KAP $^{+}$ & $0.069834^{*}$ & 0.0000 \\
LIND $^{+}$ & $-0.011172^{*}$ & 0.0019 \\
NBLJ $^{+}$ & $-0.025881 * *$ & 0.0273 \\
\hline DUM & $0.014529 * * *$ & 0.0715 \\
\hline C & $0.397283 *$ & 0.0006 \\
\hline
\end{tabular}

\begin{tabular}{|l|r|}
\hline F-statistic & 9.919753 \\
\hline Prob(F-statistic) & 0.000000 \\
\hline Note: * significant at $1 \%$ significance level, \\
$\quad * *$ significant at $5 \%$ significance level, \\
*** significant at $10 \%$ significance level \\
+ in Naturallogarithm form
\end{tabular}

This means all dependent variables, per capita GRDP (KAP), industrial sector share towards GRDP (SIND), number of workers in industrial sector (LIND), routine spending for government officials (BLJPGW), government spending for development program (NBLJ), population growth (GPOP), earthquake dummy (DUM), or at least there is one dependent variable significant affecting income distribution inequality in West Sumatera (Table 4). Testing 
parameter using t-test with $99 \%$ confidence interval shows three significant variables, per capita GRDP (KAP), industrial sector share towards GRDP (SIND), number of workers in industrial sector (LIND) affecting income distribution inequality, while all variables are significant with $90 \%$ confidence interval.

\section{A. Per Capita Income}

Per capita income is significant at rate of $1 \%$ positively towards the raise of income distribution inequality. Per capita income has strong influence on the raise of income distribution inequality in West Sumatera with elasticity of 0.069834 . This value reflects that $1 \%$ growth in per capita income will raise income distribution inequality for $0.0698 \%$ ceteris paribus. This result is in line with the research done by Nikoloski (2009) that suggests economic growth will raise income inequality among the people.

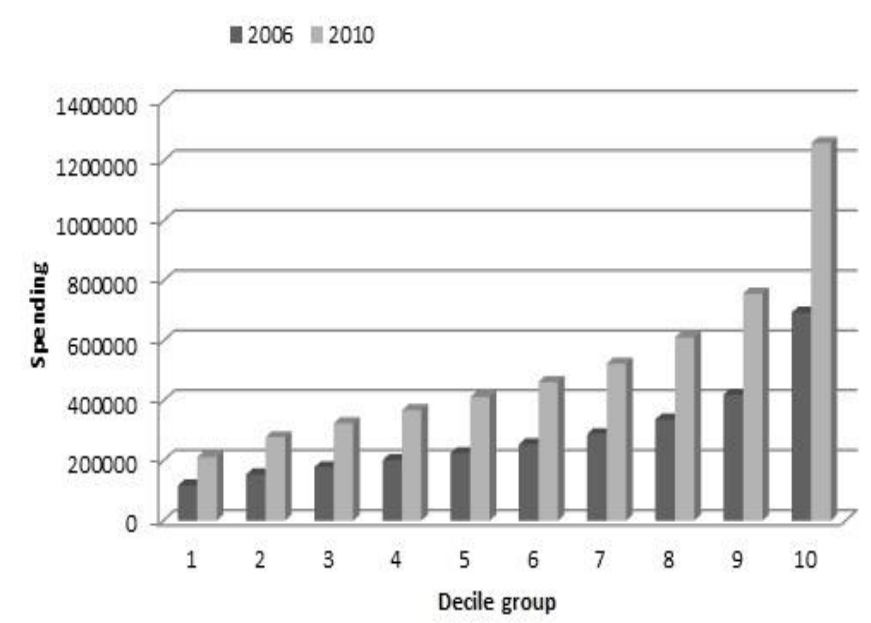

Fig. 1. Share of consumption by Income group in West Sumatera

The results of this research correspond to the phenomenon where the benefits of growth results in West Sumatra are mostly distributed only on $10 \%$ top income class. Proportionally, part of income that is spent for consumption by population at high income class in period of 2006 to 2010 is increasing significantly compared to the population at lower income class (Figure 1)

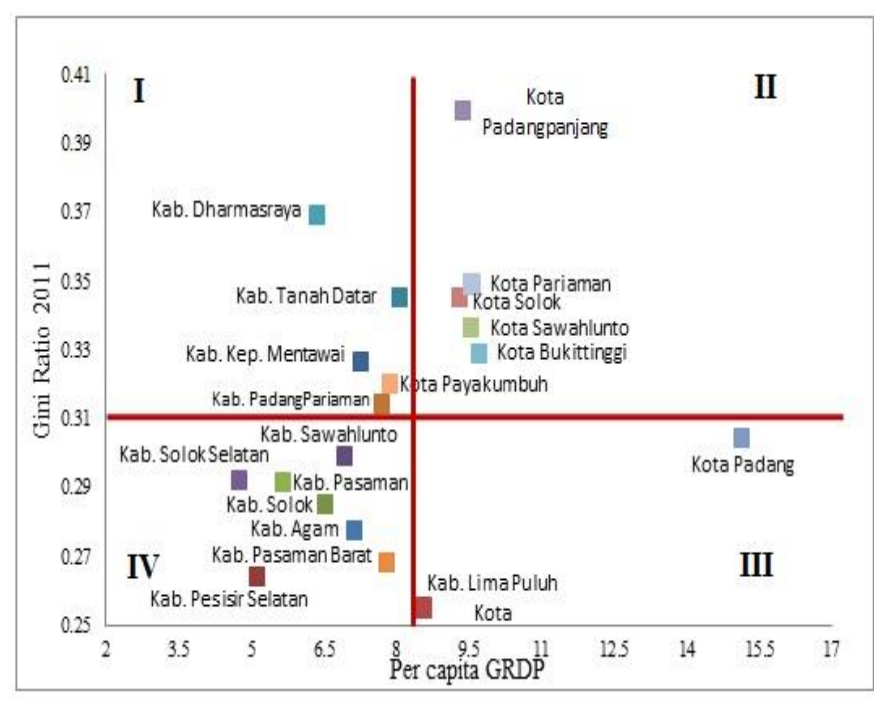

Fig. 2. Inequality and average income for each Regency/Municipality in West Sumatera

The relation between per capita income and Gini ratio for Regency/Municipality in West Sumatera in 2011 can be seen in Figure 2. The perpendicular line on per capita income is the average per capita income in West Sumatera, 8.03 million rupiah, while perpendicular line on Gini ratio is the average of Gini ratio in West Sumatera, 0.31.

First quadrant is the worst condition that shows the area with income inequality (Gini ratio) above average and income rate below average. Kab. Dhamasraya, Kab. Tanah Datar, Kab. Kep. Mentawai, Kota Payakumbuh and Kab. Padang Pariaman fall in first quadrant. Second quadrant shows the area that has relatively high per capita income and followed by Gini ratio that is above average. There are five Regency/Municipality that fall in second quadrant, which are; Kota Padang Panjang, Kota Pariaman, Kota Solok, Kota Sawah Lunto and Kota Bukittinggi. Third quadran is considered ideal condition, it is the opposite of first quadrant where per capita income is above average and low income inequality as compared to other kabubaten/kota. Only two Regency/Municipality that fall into this quadrant, Kota Padang and Kab. Lima Puluh Kota. Many Regency/Municipality fall into fourth quadrant in which it has low income inequality but its per capita income also fall below average of per capita income in West Sumatera. There are 7 Regency/Municipality that fall into this quadrant; Kab. Sawah Lunto, Kab. Solok Selatan, Kab. Pasaman, Kab. Pasaman Barat and Kab. Pesisir Selatan (Figure 2). 


\section{B. Industrial Sector's Share Towards GRDP}

Second variable that influences income distribution inequality is industrial sector share towards GRDP which is significant at $1 \%$ significance level with negative relation. This variable has elasticity of -0.031069 which means if there is an increase of $1 \%$ in industrial sector share towards GRDP, income distribution inequality will be declined at $00301 \%$ ceteris paribus. The result of this study is in line with the finding from Kassa (2003).

Industrial sector share towards GRDP lower income distribution inequality because productivity and wage rate at that sector is higher than agricultural sector, therefore it will increase the income and population prosperity as a whole. Kuznets (1955) suggests that development process will result the shift of resources from agricultural sector to industrial sector and it will gradually lower income inequality.

\section{Population Growth}

The next variable that is proved to be significant in influencing income distribution inequality in West Sumatera is population growth which is significant at $10 \%$ significance level with negative relation. Population growth has the coefficient of -0.030093 which means that the increase of population growth by 1 person will result the decline of 0.0300 ceteris paribus for income distribution inequality. This result is in line with findings by Kassa (2003) and Sylwester (2003).

Population growth occurs because of nativity. The increase in nativity also means the increase of population at productive age, therefore it can lower income distribution inequality. Area with high population density reflect the condition where the population is diverse and with high productivity, this will create mobile society that leads to fairer income distribution in the long run (Sylwester 2003). Kassa (2003) argues that area with low population has higher probability in doing land concentration that will lead to the increase in income distribution inequality.

\section{Government spending for development program}

Government spending for development program variable is significant at 5\% significance level with negative relation towards
Inequality of Income Distribution. This variable has elasticity of -0.025881 which means if there is an increase of $1 \%$ in government spending for development program, income distribution inequality will decline 0.0258 ceteris paribus. The result of this research is in line with finding from Afonso et al. (2008). Cornia and Kiiski (2001) mentions the contribution of government spending towards income distribution is influenced by the composition of that spending especially on social transfer for public expenses. Therefore, Government spending for development program such as subsidy, transfer and capital expenditure for development will decrease income distribution inequality because it will boost income and middle class and low class prosperity.

\section{E. Routine spending for government officials}

Contrast with Government spending for development program variable, Routine spending for government officials variable is significant at $10 \%$ significance level with positive relation. This variable has elasticity of 0.017330 which means that if there is an increase of $1 \%$ in Routine spending for government officials, income distribution inequality will increase 0.0173 ceteris paribus. Routine spending for government officials will only be received by middle class who serve the government, not by all population. Therefore Routine spending for government officials will increase income distribution inequality

\section{F. Dummy Earthquake}

Other variable that influences income distribution inequality is dummy earthquake. This indicates income distribution inequality will increase after the occurrence of earthquake in Regency/Municipality affected by earthquake. Dummy earthquake variable has coefficient 0.014529 , it can be translated that income distribution inequality is increased by 0.014529 after the earthquake in the affected Regency/Municipality. This result is in line with the findings from Yamamura (2013) and Rodriguez-Oreggia et al. (2010).

The effect of earthquake will worsen the condition for low population class because they have only limited income therefore it is hard for them to invest, this makes it difficult for them to recover economically after the earthquake. 
According to Rodriguez-Oreggia et al. (2010) natural disaster tend to cause poverty.

\section{G. Number of Workers in Industrial Sector}

Number of workers in industrial sector influences income distribution inequality significantly with negative relation. Elasticity of this variable is -0.011172 that means for every $1 \%$ increase of number of workers in industrial sector, there is $0.0111 \%$ decline in income distribution inequality ceteris paribus. Number of workers in industrial sector indicates that the workers have high productivity and higher wage compared to agricultural sector, therefore the increase in number of workers in industrial sector will reduce income distribution inequality in West Sumatera because it is proportional to the inclination of average income.

\section{CONCLUSION AND RECOMMENDATION}

Based on above discussion, it can be concluded that:

1. Gini ratio value from 2006 to 2011 for each Regency/Municipality in West Sumatera shows various trend. Although there is a tendency to increase.

2. Through the calculation of the Gini ratio, it was found that the highest income distribution inequality in Regency/Municipality level in West Sumatra from 2006 to 2011 are owned by the Mentawai Islands District with an average Gini ratio is 0.311, while the lowest income distribution inequality of the average owned by the Pesisir Selatan District with an average Gini ratio is 0.217.

3. Economic growth, Routine spending for government officials and earthquake led to higher inequality of income distribution.

4. Industrial sector share towards GRDP, Government spending for development program and number of workers in industrial sector can decrease income distribution inequality in West

Below are several suggestion for government based on the study:

1. Government should pursuing economic growth through higher contribution in industrial sector, Government spending for development program and number of workers in industrial sector

2. It is recommended for Government of each Regency/Municipality in West Sumatera to support industrial sector to help reducing income distribution inequality.

3. Government of Regency/Municipality in West Sumatera is advised to focus on Government spending for development program instead of routine spending for government officials.

4. Government has a main responsibility to provide the population with necessary education to help increasing number of workers in industrial sector.

5. Proper mechanism for aid and social transfer is very important matters to be addressed by government after natural disaster, in this case is earthquake.

\section{REFERENCES}

Afonso A, Schuknecht L, Tanzi V. 2008. Income Distribution Determinants and Public Spending Efficiency. Working Paper No.861. Eropa: European Central Bank

Arsyad L. 1997. Ekonomi Pembangunan. Ed 3 Yogyakarta (ID): Bagian Penerbitan STIE YKPN

Barro RJ. 2008. Inequality and Growth Revisited. Working Paper Series On Regional Economic Integration No.11 Amerika Serikat (US): Asian Development Bank

Basdevant O, Benicio D, Yakhshilikov. 2012. Inequalities and growth in the Southern African Customs Union (SACU) Region. Afrika Selatan (tZA): IMF Working Paper

[BI] Bank Indonesia. 2013. Kajian Ekonomi Regional Provinsi Sumatera Barat. Padang (ID): BI Wilayah VIII.

[BPS] Badan Pusat Statistik Provinsi Sumatera Barat. 2007-2012. Daerah dalam Angka Provinsi Sumatera Barat. Padang (ID): BPS Provinsi Sumatera Barat.

Cornia GA, Kiiski S. 2001. Trends in Income Distribution in the Post-World War II Period. Discussion Paper No.2001/89 Amerika Serikat (US): UNU/WIDER

Eicher T, Garcia-Penalosa C. 2000. Inequality And Growth: The Dual Role Of Human Capital In Development. Working Paper No. 355. Jerman (DE): Leibniz Institute for Economic Research at the University of Munich (CESifo) 
Firdaus M. 2011. Aplikasi Ekonometrika untuk Data Panel dan Time Series. Bogor (ID): IPB Press

Gujarati DN. 2004. Basic Econometrics 4th Edition. New York: McGraw Hill

Kassa A. 2003. Factors Influencing Income Inequality in Transition Economies. Tartu: Tartu University Press

Kuznets S. 1955. Economic Growth and Income Inequality. The American Economic Review. Vol 45, Issue 1 (Mar.,1955), 1-28. Amerika Serikat (AS): JSTOR.

Nikoloski Z. 2009. Economic and Political Determinants of Income Inequality. London (GB): University College London

Ray D. 1998. Development Economics. New Jersey: Princeton University Press

Rodriguez-Oreggia E, Fuente A, Torre R, Moreno H, Rodriguez C. 2010. The Impact of Natural Disaster on Human Development and Poverty at the Municipal Level in Mexico. CID Working Paper No. 43. Harvard (US): Center for International Development at Harvard University

Sylwester K. 2003. Income Inequality and Population Density 1500 AD: A Connection. Journal of Economic Development. Vol XXVIII No.2. Carbondale (US): Department of Economics.

Todaro MP, Smith SC. 2006. Pembangunan Ekonomi. Jilid 1. Ed 9. Yelvi A, penerjemah; Barnadi D, Hardani W, editor. Jakarta (ID): Penerbit Erlangga.

Yamamura E. 2013. Impact of Natural Disaster on Income Inequality: Analysis Using Panel Data During the Period 1965 to 2004. MPRA Paper No. 45623. Muenchen: Munich Personal RePEc Archive MPRA 